\title{
Sensitivity of Colletotrichum truncatum to Four Fungicides and Characterization of Thiabendazole-Resistant Isolates
}

C. Torres-Calzada, and R. Tapia-Tussell, Laboratorio GeMBio, Centro de Investigación Científica de Yucatán A.C., Mérida, Yucatán 97200, México; I. Higuera-Ciapara, Unidad de Tecnología de Alimentos, Centro de Investigación y Asistencia Tecnológica y Diseño del Estado de Jalisco A.C., Guadalajara, Jalisco 44270, México; and R. Martin-Mex, A. Nexticapan-Garcez, and D. Perez-Brito, Laboratorio GeMBio, Centro de Investigación Científica de Yucatán A.C.

\begin{abstract}
Torres-Calzada, C., Tapia-Tussell, R., Higuera-Ciapara, I., Martin-Mex, R., Nexticapan-Garcez, A., and Perez-Brito, D. 2015. Sensitivity of Colletotrichum truncatum to four fungicides and characterization of thiabendazole-resistant isolates. Plant Dis. 99:1590-1595.

Anthracnose, caused by Colletotrichum truncatum (syn. C. capsici), has become a common disease of tropical crops, severely affecting the quantity and quality of fruit and seed and, therefore, reducing their market value. For years, chemical control has been extensively used for managing this disease. However, the appearance of isolates that are resistant to the most commonly employed fungicides is increasingly widespread. Twenty $C$. truncatum isolates from pepper, papaya, and physic nut were tested in vitro against four fungicides to determine their sensitivity. All evaluated isolates were resistant to

azoxystrobin and thiabendazole and susceptible to cyprodinil + fludioxonil and mancozeb. To determine the molecular mechanism conferring thiabendazole resistance, the $T U B-2$ gene was characterized, revealing a glutamic acid to alanine substitution at position 198 in 6 of the 20 isolates that were tested. This work confirms the emergence of benzimidazole-based fungicide resistance in $C$. truncatum populations and highlights the need for monitoring fungicide sensitivity as an essential activity for the development of effective control schemes.
\end{abstract}

Anthracnose, caused by species in the genus Colletotrichum, is one of the most common diseases affecting plants (Bailey and Jeger 1992). The losses caused by this disease are mainly due to the direct reduction in the quality and quantity of the harvested product. Usually, the fungus infects more than one part of the plant, which results in multiple cycles of infection throughout the growing season (Waller 1992). In Mexico, Colletotrichum truncatum (Schwein.) Andrus \& W. D. Moore (syn. C. capsici (Syd. \& P. Syd) E. J. Butler \& Bisby) (Damm et al. 2009) was identified as the causative agent of anthracnose in multiple hosts, including pepper (Capsicum annuum L. and C. chinense Jacq.), papaya (Carica papaya L.), and physic nut (Jatropha curcas L.). This pathogen severely affects the quantity and quality of the fruit and seed, reducing their market value.

Effective control of the disease includes a set of chemical, cultural, and biological practices. For chemical control, several fungicides, mainly in the benzimidazole class, have been extensively used in the field. However, it is increasingly common to find isolates that are less sensitive or even resistant to these fungicides, as has been seen in populations of Colletotrichum gloeosporioides (Astúa et al. 1994; Peres et al. 2004; Solano and Arauz 1995). The benzimidazole fungicides act by binding to the $\beta$-tubulin molecule and disrupting microtubule-based processes, which inhibits nuclear division (Brennan et al. 2007). Resistance to benzimidazole fungicides is conferred by a single nucleotide mutation in the $\beta$-tubulin gene, and different levels of resistance have been reported in several fungal pathogens (Chung et al. 2006; Wong et al. 2008). This resistance has been attributed to missense point mutations in DNA, resulting in amino acid exchanges in the $\beta$-tubulin protein (Ma and Michailides 2005). Molecular analysis revealed four amino acid substitutions that led to the development of resistance to thiabendazole. The substitutions of glutamic acid (E) by alanine (A), glycine $(\mathrm{G})$, or lysine $(\mathrm{K})$ at position 198 or of phenylalanine $(\mathrm{F})$ by tyrosine $(\mathrm{Y})$ at position 200 conferred resistance. Previous studies proposed that these resistance-conferring

Corresponding author: D. Perez-Brito; E-mail: daisypb@cicy.mx

Accepted for publication 30 April 2015.

http://dx.doi.org/10.1094/PDIS-11-14-1183-RE

(C) 2015 The American Phytopathological Society mutations enabled the formation of hydrogen bonds, closing off the tubulin-binding pocket and, thus, decreasing the binding affinity (Brennan et al. 2007).

The strobilurins (quinone outside inhibitors [QoI]) are a different group of fungicides that are used against many diseases, including anthracnose (Avila-Adame et al. 2003). These fungicides inhibit mitochondrial respiration by binding to the Qo center of cytochrome $b$, thereby blocking the transfer of electrons between cytochromes $b$ and c1 and halting the production of ATP (Fernández-Ortuño et al. 2012). Several phytopathogenic fungi have developed resistance to QoI fungicides and, for most of them, the mechanism of resistance is the amino acid substitution of glycine by alanine at position 143 (G143A) of the cytochrome b protein (Banno et al. 2009; Farman 2001; Gisi et al. 2002; Grasso et al. 2006; Kim et al. 2003; Ma et al. 2003). The F129L and G137R mutations have been reported as mechanisms for QoI tolerance in Alternaria solani and Pyrenophora teres but these changes are considered of lesser importance because they lead to lower resistance levels than the G143A mutation (Stammler et al. 2013).

Monitoring fungicide resistance is crucial to achieving effective control of anthracnose disease. No previous reports have explored the resistance in the $C$. truncatum populations in Mexico. Thus, the objectives of this study were to (i) determine the sensitivity of C. truncatum isolates obtained from various host species (papaya, pepper, and physic nut) to four different fungicides (thiabendazole, azoxystrobin, mancozeb, and cyprodinil + fludioxonil) and (ii) characterize the thiabendazole-resistant genotypes based on amino acid sequence comparisons of the $T U B-2$ gene.

\section{Materials and Methods}

Isolate collection and molecular characterization. $C$. truncatum isolates were selected from previously collected samples that were obtained from lesions on leaves, fruit, and seed from diseased plants of papaya, pepper, and physic nut, which were sampled in five different states in Mexico (Table 1). Pure cultures were obtained by singlespore isolation and maintained on potato dextrose agar (PDA) plates at $25^{\circ} \mathrm{C}$. The identity of the isolates was determined by polymerase chain reaction (PCR) using species-specific primers. The conditions of the PCR (25- $\mu$ l final volume) were as follows: $25 \mathrm{ng}$ of DNA, 1× PCR buffer (pH 8.4; stock number CAUB1g; Invitrogen, Sao Paulo, Brazil), $0.20 \mathrm{mM}$ each dNTP (Invitrogen, Carlsbad, CA), $1.5 \mathrm{mM}$ $\mathrm{MgCl}_{2}, 1 \mu \mathrm{M}$ primers, and $1 \mathrm{U}$ of $\mathrm{Taq}$ polymerase (Invitrogen). 
DNA amplification was performed in a GeneAmp 9700 DNA Thermal Cycler (PE Biosystems, Foster City, CA). The protocol consisted of an initial denaturing step at $95^{\circ} \mathrm{C}$ for $5 \mathrm{~min} ; 25$ cycles of $30 \mathrm{~s}$ at $94^{\circ} \mathrm{C}$, $2 \mathrm{~min}$ at $62^{\circ} \mathrm{C}$, and $2 \mathrm{~min}$ at $72^{\circ} \mathrm{C}$; and a final extension step of $5 \mathrm{~min}$ at $72^{\circ} \mathrm{C}$. The PCR products were separated by electrophoresis in $1.5 \%$ (wt/vol) agarose gels and visualized by ethidium bromide staining (Torres-Calzada et al. 2011).

Selection of fungicides. Four fungicides were selected, based on their current use to control the disease in Mexico. Commercial formulations were used and obtained from local suppliers (Table 2). The ability to observe a more accurate response of the pathogen would be achieved by using the commercial formulations instead of the active ingredient. Thiabendazole and mancozeb were prepared from commercial formulations dissolved in dimethyl sulfoxide (DMSO) as stock solutions of 10,000 and 1,000 $\mu \mathrm{g} / \mathrm{ml}$, respectively. Azoxystrobin was diluted in methanol as a stock solution of $10,000 \mu \mathrm{g} / \mathrm{ml}$. The final concentration of DMSO was $0.05 \%$ and of methanol was $0.07 \%$. Cyprodinil + fludioxonil was prepared at a concentration of $100 \mu \mathrm{g} / \mathrm{ml}$ in sterile distilled water.

In vitro assessment of fungicide sensitivity. The sensitivity of the Colletotrichum isolates to the different fungicides was determined with mycelia growth assays. Each isolate was plated onto PDA at $25^{\circ} \mathrm{C}$. Plugs $(5 \mathrm{ml})$ were punched from actively sporulating areas near the growing edge of a 5-day-old culture of these isolates. Mycelia plugs were placed upside down onto PDA dishes treated with cyprodinil + fludioxonil at $0,0.01,0.1,1$, and $10 \mu \mathrm{g}$ active ingredient (a.i.)/ml; mancozeb at $0,0.1,1,10$, and $100 \mu \mathrm{g}$ a.i./ml; or

Table 1. Colletotrichum truncatum isolates selected for the in vitro sensitivity assays

\begin{tabular}{lllc}
\hline Isolate & \multicolumn{1}{c}{ Host } & \multicolumn{1}{c}{ Origin $^{\mathbf{z}}$} & Collection year \\
\hline CCP4 & Carica papaya & Champoton, CAM & 2009 \\
CCP6 & C. papaya & Morelos, ROO & 2009 \\
CCP27 & C. papaya & Tizimin, YUC & 2012 \\
CCP31 & C. papaya & Balankan, TAB & 2012 \\
CCP43 & C. papaya & Arriaga, CHS & 2013 \\
CCG9 & Capsicum annuum & Peto, YUC & 2008 \\
CCG12 & C. annuum & Tekax, YUC & 2008 \\
CCC3 & C. annuum & Balankan, TAB & 2012 \\
CCC18 & C. annuum & Balankan, TAB & 2012 \\
CCC30 & C. annuum & Calkiní, CAM & 2012 \\
CCC33 & C. chinense & Chiapa de Corzo, CHS & 2012 \\
CCC38 & C. chinense & Chiapa de Corzo, CHS & 2012 \\
CCC43 & C. annuum & Conkal, YUC & 2012 \\
CCC60 & C. chinense & Solidaridad, ROO & 2013 \\
CCG14 & Jatropha curcas & Uman, YUC & 2008 \\
CCJ2 & J. curcas & Muna, YUC & 2012 \\
CCJ11 & J. curcas & Tekax, YUC & 2012 \\
CCJ13 & J. curcas & Merida, YUC & 2012 \\
CCJ19 & J. curcas & Opichen, YUC & 2012 \\
CCJ20 & J. curcas & Chiapa de Corzo, CHS & 2013 \\
\hline
\end{tabular}

z $\mathrm{CAM}=$ Campeche, $\mathrm{CHS}=$ Chiapas, $\mathrm{ROO}=$ Quintana Roo, $\mathrm{TAB}=$ Tabasco, and YUC = Yucatán. azoxystrobin or thiabendazole at $0,10,100,1,000$, and 10,000 $\mu \mathrm{g}$ a.i./ml. For the azoxystrobin sensitivity assay, an additional test was performed. Salicylhydroxamic acid (SHAM), at a final concentration of $100 \mu \mathrm{g} / \mathrm{ml}$, was added to the culture media instead of the fungicide to observe the effect of the alternative oxidase on in vitro growth. The plates were incubated at $25^{\circ} \mathrm{C}$ for 5 days. Control plates consisting of a plug ( $5 \mathrm{~mm}$ in diameter) of the isolates were placed onto nonamended PDA. The experiment was repeated twice, with four replicates per isolate and concentration. The diameter of each colony was used to calculate the percent relative growth (\%RG) compared with the control and the percent relative growth inhibition (\% $\mathrm{RGI}=100-\% \mathrm{RG})$. The $50 \%$ effective dose $\left(\mathrm{ED}_{50}\right)$ value was determined by plotting the \% RG on each fungicide-amended medium compared with the growth on the control versus the log concentration of the fungicide treatment; then, the regression line through the linear portion of the dose-response curve was calculated (Wong et al. 2008). A one-way analysis of variance was conducted to determine the significance of differences. Means were compared using Tukey's multiple range tests with the statistical software R v. 2.14.0 (R Core Team).

For all assays, isolates with $\mathrm{ED}_{50}$ values $<10 \mu \mathrm{g} / \mathrm{ml}$ were considered susceptible, and isolates with $\mathrm{ED}_{50}$ values of 10 to $100 \mu \mathrm{g} / \mathrm{ml}$ were grouped as intermediate resistant. Finally, isolates with $\mathrm{ED}_{50}$ values greater than $100 \mu \mathrm{g} / \mathrm{ml}$ were considered highly resistant (Chung et al. 2006).

Molecular identification of thiabendazole-resistant isolates. The resistance or sensitivity of the isolates to thiabendazole was further evaluated by sequencing the $T U B-2$ gene. Total genomic DNA was extracted according to the method described by Tapia-Tussell et al. (2006) and diluted to a final concentration of $50 \mathrm{ng} / \mu \mathrm{l}$. The PCR mixture and reaction program used were those reported by Wong et al. (2008). The TUB-2 gene, including the amino acid codons 198 and 200, was amplified using the TUB2-1 and TUB22 primer pair (Wong et al. 2008). DNA amplification was performed in a C1000 Touch Thermal Cycler (Bio-Rad). The protocol consisted of an initial denaturing step at $95^{\circ} \mathrm{C}$ for $1 \mathrm{~min} ; 30$ cycles of $1 \mathrm{~min}$ at $94^{\circ} \mathrm{C}, 1 \mathrm{~min}$ at $57^{\circ} \mathrm{C}$, and $1 \mathrm{~min}$ at $72^{\circ} \mathrm{C}$; and a final extension step of $1 \mathrm{~min}$ at $72^{\circ} \mathrm{C}$. The PCR products were separated by electrophoresis in $1.5 \%$ (wt/vol) agarose gels and visualized by ethidium bromide staining. The PCR products were purified and sequenced by Macrogen Inc. (Seoul, Korea). Alignment was performed with the BioEdit Sequence Alignment program (Altschul et al. 1990).

\section{Results}

Colletotrichum isolates were collected from papaya, pepper, and physic nut (Table 1). Each isolate was subjected to PCR with the species-specific primers CcapF and CcapR. All isolates amplified a 394-bp DNA fragment that was indicative of $C$. truncatum (Torres-Calzada et al. 2011) (Fig. 1).

In vitro assessment of fungicide sensitivity. Differences in the sensitivities to the fungicides were observed for all isolates (Table 3). The calculated $\mathrm{ED}_{50}$ for the thiabendazole experiment were 6.6 to $2,673.9 \mu \mathrm{g} / \mathrm{ml}$. Most of the isolates had intermediate or high resistance to this fungicide. Similar results were obtained with the isolates evaluated against azoxystrobin. The $\mathrm{ED}_{50}$ values for this

Table 2. Fungicides used in the Colletotrichum truncatum assays.

\begin{tabular}{|c|c|c|c|c|c|c|}
\hline Active ingredient & Manufacturer & $\begin{array}{l}\text { Trade } \\
\text { name }\end{array}$ & $\begin{array}{l}\text { FRAC } \\
\text { group }\end{array}$ & $\begin{array}{l}\text { Maximum } \\
\text { rate }\end{array}$ & Chemical group & $\begin{array}{l}\text { Mode of action, } \\
\text { target site }\end{array}$ \\
\hline Thiabendazole $(60 \%)$ & $\begin{array}{l}\text { Syngenta Crop } \\
\text { Protection }\end{array}$ & Tecto & 1 & $2.0 \mathrm{~kg} / \mathrm{ha}$ & Benzimidazoles & $\begin{array}{l}\text { B1: } \beta \text {-tubulin assembly in } \\
\text { mitosis }\end{array}$ \\
\hline Mancozeb (80\%) & BASF, Corporation & Dithane & M13 & $2.5 \mathrm{~kg} / \mathrm{ha}$ & Dithiocarbamates & Multisite contact activity \\
\hline Azoxystrobin $(50 \%)$ & $\begin{array}{l}\text { Syngenta Crop } \\
\text { Protection }\end{array}$ & Amistar & 11 & $500 \mathrm{mg} / \mathrm{ha}$ & Methoxy-acrylates & $\begin{array}{l}\text { C3: complex III cytochrome } \\
\text { bc1 at the QoI site }\end{array}$ \\
\hline Cyprodinil (37.5\%) + Fludioxonil (25\%) & $\begin{array}{l}\text { Syngenta Crop } \\
\text { Protection }\end{array}$ & Switch & 9 & $1.0 \mathrm{~kg} / \mathrm{ha}$ & Anilino-pyrimidines & D1: methionine biosynthesis \\
\hline$\ldots$ & $\ldots$ & $\ldots$ & 12 & $\ldots$ & Phenylpyrroles & $\begin{array}{l}\text { E2: MAP/ Histidine- kinase in } \\
\text { osmotic signal transduction }\end{array}$ \\
\hline
\end{tabular}


fungicide were 37.2 to $6,318.7$. The $1,000 \mu \mathrm{g} / \mathrm{ml}$ concentration was effective at inhibiting the growth of most of the isolates but five of the total analyzed isolates were resistant and required higher doses of the fungicide (Table 4). Previous assays indicated that the addition of SHAM was not necessary because its absence did not enable the pathogen to grow in the presence of the fungicide (data not shown). With mancozeb, $90 \%$ of the isolates were susceptible, showing $\mathrm{ED}_{50}$ values between 0.6 and $7.4 \mu \mathrm{g} / \mathrm{ml}$, and only two isolates had intermediate resistance, with $\mathrm{ED}_{50}$ values between 23.30 and $36.50 \mu \mathrm{g} / \mathrm{ml}$. No highly resistant isolates were found with this fungicide. All isolates were susceptible to cyprodinil + fludioxonil, with the $\mathrm{ED}_{50}$ values ranging from 0.007 to $0.37 \mu \mathrm{g} / \mathrm{ml}$. Generally, the CCC 38 , CCC43, CCJ11, and CCJ13 isolates were the most sensitive to the four fungicides and exhibited the lowest $\mathrm{ED}_{50}$ values in the experiments.

Importance of host in $\boldsymbol{C}$. truncatum resistance. Results from the sensitivity bioassay showed that isolates of $C$. truncatum that were collected from physic nut were more sensitive to azoxystrobin than isolates from papaya and pepper (Table 5).

According to the results of the thiabendazole assay, $80 \%$ of isolates from papaya were highly resistant, and similar levels of resistance were found in the pepper isolates, with only two of the isolates considered susceptible. In contrast, $67 \%$ of the isolates collected from physic nut were classified as susceptible to thiabendazoles. In general, the isolates had low levels of resistance (susceptible) against mancozeb. Among them, however, the isolates from

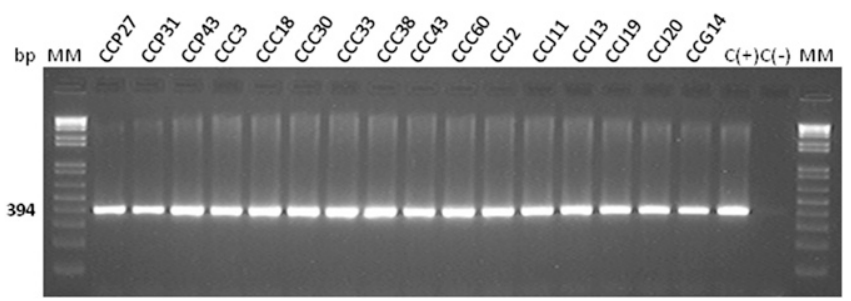

Fig. 1. Amplification products obtained using the species-specific primers $\mathrm{CcapF}$ and CcapR for detecting Colletotrichum truncatum. Lane MM, DNA marker (1-kb DNA ladder); lanes 1 to 16, C. truncatum isolates; lane 17, C. capsici ATCC 48574; and lane 18 , negative control. physic nut required higher doses of this fungicide (Table 3 ). The lowest levels of fungicide resistance were obtained with cyprodinil + fludioxonil, showing very low growth in all isolates compared with the controls.

The results of the comparison of the $C$. truncatum isolates according to the information of fungicide exposure in commercial fields are presented in Table 5. The isolates were grouped according to their host, and there were significant differences $(P \leq 0.05)$ among the doses employed to reduce their growth at $50 \%$ compared with the control between isolates from physic nut and papaya and pepper isolates using azoxystrobin. There were no differences among the isolates grouped by host against other fungicides. Additionally, there

Table 4. Percent relative growth inhibition (RGI) for all Colletotrichum truncatum isolates used in the azoxystrobin assay

\begin{tabular}{lcccccc}
\hline & \multicolumn{6}{c}{ RGI (\%) for each fungicide concentration $\left(\boldsymbol{\mu g} \mathbf{~ m l}^{-\mathbf{1}}\right)$} \\
\cline { 2 - 7 } Isolate & Control & Control + SHAM $^{\mathbf{2}}$ & $\mathbf{1 0}$ & $\mathbf{1 0 0}$ & $\mathbf{1 , 0 0 0}$ & $\mathbf{1 0 , 0 0 0}$ \\
\hline CCP4 & 0 & 1.32 & 26.86 & 30 & 51.25 & 100 \\
CCP6 & 0 & 0.26 & 37.04 & 48.30 & 51.11 & 100 \\
CCP27 & 0 & 1.58 & 20.26 & 22.62 & 33.03 & 63.71 \\
CCP31 & 0 & 3.0 & 12.99 & 28.25 & 46.97 & 72.72 \\
CCP43 & 0 & 0.89 & 1.90 & 7.70 & 20.65 & 70.33 \\
CCG9 & 0 & 0.69 & 10.02 & 14.31 & 32.59 & 99.72 \\
CCG12 & 0 & 1.99 & 14.81 & 37.55 & 56.19 & 100 \\
CCC3 & 0 & 1.75 & 37.59 & 48.57 & 69.03 & 99.39 \\
CCC18 & 0 & 0.92 & 5.13 & 13.82 & 24.68 & 68.07 \\
CCC30 & 0 & 1.26 & 38.53 & 49.78 & 54.59 & 100 \\
CCC33 & 0 & 0.68 & 32.84 & 44.06 & 55.61 & 100 \\
CCC38 & 0 & 1.8 & 42.47 & 52.56 & 62.36 & 100 \\
CCC43 & 0 & 0.96 & 38.90 & 50.98 & 69.88 & 99.65 \\
CCC60 & 0 & 1.76 & 42.78 & 51.65 & 87.84 & 100 \\
CCG14 & 0 & 1.71 & 18.02 & 47.14 & 65.73 & 100 \\
CCJ2 & 0 & 1.93 & 27.90 & 49.43 & 61.36 & 100 \\
CCJ11 & 0 & 2.21 & 38.24 & 63.94 & 74.34 & 95.01 \\
CCJ13 & 0 & 1.77 & 44.94 & 61.38 & 79.57 & 100 \\
CCJ19 & 0 & 1.72 & 21.27 & 45.55 & 53.38 & 68.01 \\
CCJ20 & 0 & 2.33 & 33.37 & 53.89 & 62.45 & 98.65 \\
\hline
\end{tabular}

z SHAM = salicylhydroxamic acid.

Table 3. Value for $50 \%$ effective dose $\left(\mathrm{ED}_{50}\right)$ of four fungicides on the radial growth suppression of isolates of Colletotrichum truncatum grown on fungicideamended potato dextrose agar

\begin{tabular}{|c|c|c|c|c|}
\hline \multirow[b]{2}{*}{ Isolate } & \multicolumn{4}{|c|}{$E D_{50}\left(\mu \mathrm{g} \mathrm{ml}^{-1}\right)^{z}$} \\
\hline & Thiabendazole & Azoxystrobin & Mancozeb & Cyprodinil + fludioxonil \\
\hline CCP4 & $81.6 \mathrm{j}$ (IR) & $947.3 \mathrm{e}(\mathrm{HR})$ & $3.60 \mathrm{~h}(\mathrm{~S})$ & 0.045 e $(\mathrm{S})$ \\
\hline СCP6 & 2673.9 a (HR) & $325.3 \mathrm{i}$ (HR) & 0.60 no $(\mathrm{S})$ & $0.37 \mathrm{a}(\mathrm{S})$ \\
\hline ССР27 & $689.8 \mathrm{~g}(\mathrm{HR})$ & $5980.0 \mathrm{~b}(\mathrm{HR})$ & 36.50 a (S) & $0.008 \mathrm{~h}(\mathrm{~S})$ \\
\hline CCP31 & 463.5 h (HR) & $1145.9 \mathrm{~d}(\mathrm{HR})$ & $2.20 \mathrm{j}(\mathrm{S})$ & 0.008 h (S) \\
\hline ССР43 & 305.3 i (HR) & $6318.7 \mathrm{a}(\mathrm{HR})$ & $0.8 \mathrm{mn}(\mathrm{S})$ & $0.019 \mathrm{~g}(\mathrm{~S})$ \\
\hline CCG9 & 910.7 d (HR) & $3335.1 \mathrm{c}(\mathrm{HR})$ & $5.0 \mathrm{f}(\mathrm{S})$ & $0.027 \mathrm{f}(\mathrm{S})$ \\
\hline CCG12 & 750.4 e (HR) & $701.3 \mathrm{f}(\mathrm{HR})$ & 0.70 no $(\mathrm{S})$ & $0.009 \mathrm{~h}(\mathrm{~S})$ \\
\hline $\mathrm{CCC} 3$ & 920.6 d (HR) & $163.3 \mathrm{k}(\mathrm{HR})$ & $4.50 \mathrm{~g}(\mathrm{~S})$ & $0.009 \mathrm{~h}(\mathrm{~S})$ \\
\hline $\mathrm{CCC} 18$ & $1728.1 \mathrm{c}(\mathrm{HR})$ & $6252.9 \mathrm{a}(\mathrm{HR})$ & $4.60 \mathrm{~g}(\mathrm{~S})$ & $0.008 \mathrm{~h}(\mathrm{~S})$ \\
\hline $\mathrm{CCC} 30$ & $700.0 \mathrm{f}(\mathrm{HR})$ & $141.3 \mathrm{k}(\mathrm{HR})$ & $1.201(\mathrm{~S})$ & $0.121 \mathrm{~b}(\mathrm{~S})$ \\
\hline $\mathrm{CCC} 33$ & $923.0 \mathrm{~d}(\mathrm{HR})$ & $563.2 \mathrm{~h}(\mathrm{HR})$ & $8.0 \mathrm{c}(\mathrm{S})$ & $0.009 \mathrm{~h}(\mathrm{~S})$ \\
\hline $\mathrm{CCC} 38$ & $20.4 \mathrm{k}$ (IR) & 77.201 (IR) & $0.80 \mathrm{mn}(\mathrm{S})$ & $0.008 \mathrm{~h}(\mathrm{~S})$ \\
\hline $\mathrm{CCC} 43$ & $6.601(\mathrm{~S})$ & 92.701 (IR) & $0.90 \mathrm{~m}(\mathrm{~S})$ & $0.008 \mathrm{~h}(\mathrm{~S})$ \\
\hline CCC60 & $7.01(\mathrm{~S})$ & 83.301 (IR) & $7.40 \mathrm{~d}(\mathrm{~S})$ & $0.047 \mathrm{e}(\mathrm{S})$ \\
\hline CCG14 & $7.601(\mathrm{~S})$ & $238.5 \mathrm{j}(\mathrm{HR})$ & 0.50 o $(\mathrm{S})$ & $0.064 \mathrm{~d}(\mathrm{~S})$ \\
\hline $\mathrm{CCJ} 2$ & $1909.1 \mathrm{~b}(\mathrm{HR})$ & $143.2 \mathrm{k}(\mathrm{HR})$ & $1.401(\mathrm{~S})$ & $0.008 \mathrm{~h}(\mathrm{~S})$ \\
\hline CCJ11 & $7.701(\mathrm{~S})$ & $51.2 \mathrm{~m}$ (IR) & 5.80 e $(\mathrm{S})$ & $0.009 \mathrm{~h}(\mathrm{~S})$ \\
\hline CCJ13 & $7.701(\mathrm{~S})$ & 37.7 n (IR) & $1.80 \mathrm{k}(\mathrm{S})$ & $0.125 \mathrm{~b}(\mathrm{~S})$ \\
\hline CCJ19 & $8.601(\mathrm{~S})$ & $611.8 \mathrm{~g}(\mathrm{HR})$ & $2.70 \mathrm{i}(\mathrm{S})$ & $0.094 \mathrm{c}(\mathrm{S})$ \\
\hline CCJ20 & $8.101(\mathrm{~S})$ & 83.01 (IR) & $23.30 \mathrm{~b}$ (IR) & $0.007 \mathrm{~h}(\mathrm{~S})$ \\
\hline
\end{tabular}

${ }^{\mathrm{z}}$ Mean values in the same column that are followed by the same letter are significantly different $(P \leq 0.05)$ according to Tukey's honestly significant difference test. $\mathrm{S}=$ susceptible, $\mathrm{IR}=$ intermediate resistance, and $\mathrm{HR}=$ high resistance. 
were no observed differences in their response to fungicides among the isolates according to their location of origin (data not shown).

Molecular identification of thiabendazole-resistant isolates. Nucleotide sequences were obtained from the amplification of the $T U B-2$ gene from the 20 isolates. The deduced amino acid sequences, corresponding to residues 152 to 303 , contained the residues at positions 198, 200, and 240, which are typically associated with benzimidazole resistance. The mutations at the translated sequences of the isolates are shown in Figure 2 and Table 6: 82\% of the isolates that were classified as highly resistant had a point mutation from GAG to GCG at codon 198 (E198A), and one of the two isolates with intermediate resistance retained the glutamic acid (E) at position 198. However, no mutations were detected at the sequences corresponding to codons 200 (phenylalanine, F) and 240 (leucine, L). The sequences of six of the isolates revealed base substitutions that led to four different codon changes, as follows: a serine to phenylalanine at position $153(\mathrm{~S} 153 \mathrm{~F})$ for isolates CCP4 and CCP6, an aspartic acid to asparagine at position $155(\mathrm{D} 155 \mathrm{~N})$ for isolates CCG9 and CCP27, a glycine to glutamic acid at position 158 (G158E) for isolate $\mathrm{CCC} 18$, and a glycine to alanine at position 158 (G158A) for isolate CCJ20. More detailed studies are needed to evaluate these codon changes and determine their relationship to the thiabendazoleresistant phenotype of the isolates carrying them.

\section{Discussion}

In the present study, $C$. truncatum isolates from various hosts were evaluated for their sensitivities to different fungicides with diverse modes of action. The molecular mechanism conferring resistance to thiabendazole was also investigated. According to our results, isolates were classified as sensitive or having intermediate or high resistance to four commercial fungicides in a mycelia growth assay, and the relative growth of these isolates at the discriminatory doses selected was consistent with previous reports (Chung et al. 2006). The results strongly suggest the development of resistance to azoxystrobin and thiabendazole fungicides in populations of $C$. truncatum. All isolates had a similar high resistance to both fungicides, which was higher than when they were tested with other products. Additionally, we observed a high frequency $(90 \%)$ of susceptibility against mancozeb in every host and location sampled. According to the results, the site location did not influence the level of resistance or sensitivity, indicating that the isolates are distinguished based on their host. This effect may be due to the intensive production of pepper and papaya, with a constant use of fungicides during the growing season, which exposes these isolates to increased contact with these chemicals. In contrast, isolates from the physic nut had lower chemical exposure because it was only used as a living fence until recently, with its intense cultivation occurring only over the last few years.

All isolates in this study were sensitive to the fludioxonil + cyprodinil fungicide mix, suggesting that fungicide mixtures provide an adequate control of the pathogen and reduce the risk of fungicide resistance development. Further testing is needed to determine whether one of the two active ingredients is the most active in the mix or whether there is some synergy between them.

QoI are site-specific fungicides that inhibit mitochondrial respiration at the ubiquinol oxidation center site of the cytochrome bc1 enzyme complex. Since their introduction to the market, QoI have been extensively applied to control most fungal diseases. Azoxystrobin, the first QoI fungicide, was introduced for agricultural pest management in 1996 and is now registered for use on 84 different crops in 72 countries, making it the most commonly used fungicide in the world (Bartlett et al. 2002). Subsequently, the development of resistance among many plant pathogens to this material has been reported (Banno et al. 2009; Yin et al. 2012). A point mutation at codon 143 in the $c y t b$ gene, giving rise to a substitution from glycine to alanine (G143A), confers resistance to QoI, and various fungal pathogens carrying the mutation have been reported (Heaney et al. 2000; Sierotzki et al. 2007). There are other reports that F129L and G137R point mutations in the $c y t b$ gene also confer resistance to

Table 5. Comparison of Colletotrichum truncatum isolates according to fungicide and information of fungicide exposure from commercial fields ${ }^{\mathrm{z}}$

\begin{tabular}{|c|c|c|c|c|c|c|c|c|}
\hline \multirow[b]{2}{*}{ Host } & \multicolumn{2}{|c|}{$\begin{array}{c}\text { Cyprodinil + } \\
\text { fludioxonil }\end{array}$} & \multicolumn{2}{|c|}{ Mancozeb } & \multicolumn{2}{|c|}{ Azoxystrobin } & \multicolumn{2}{|c|}{ Thiabendazole } \\
\hline & $\bar{N}$ & $\overline{E^{\prime} D_{50}}$ & $\bar{N}$ & ED $_{50}$ & $\bar{N}$ & $\mathbf{E D}_{50}$ & $\bar{N}$ & ED $_{50}$ \\
\hline$\overline{\text { Papaya }}$ & 3 & $0.09 \mathrm{a}$ & 5 & $8.74 \mathrm{a}$ & 3 & $2,943.44 \mathrm{a}$ & 5 & $842.82 \mathrm{a}$ \\
\hline Pepper & 1 & $0.027 \mathrm{a}$ & 4 & $3.67 \mathrm{a}$ & 2 & $1,267.81 \mathrm{a}$ & 3 & $662.97 \mathrm{a}$ \\
\hline Physic nut & 0 & $0.051 \mathrm{a}$ & 4 & $5.91 \mathrm{a}$ & 0 & $194.23 \mathrm{~b}$ & 0 & $324.81 \mathrm{a}$ \\
\hline
\end{tabular}

${ }^{\mathrm{z}}$ Mean values in the same column and followed by the same letter are significantly different $(P \leq 0.05)$ according to Tukey's honestly significant difference test.

$N=$ number of spray applications per season based on reports by producers and $\mathrm{ED}_{50}$ indicates mean $50 \%$ effective dose $\left(\mu \mathrm{g} \mathrm{ml}{ }^{-1}\right)$.

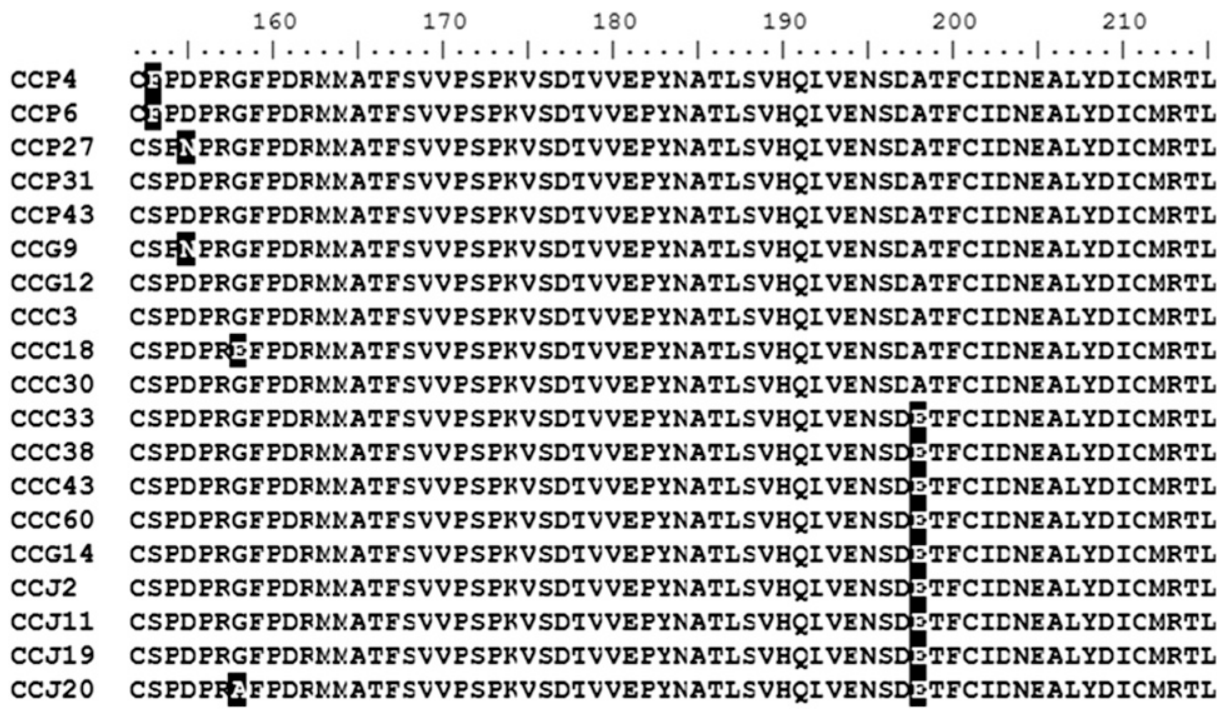

Fig. 2. Amino acid sequences spanning residues 152 to 251 of the $\beta$-tubulin protein for 20 Colletotrichum truncatum isolates. Exchanged amino acids are highlighted. 
these fungicides, but at lower levels (Farman 2001; Olaya et al. 2003). In this study, azoxystrobin did not reduce mycelia growth in all tested isolates, regardless of the location or host origin; and, according to the $\mathrm{ED}_{50}$ values obtained in the assay, $70 \%$ of the isolates were classified as highly resistant. Analysis of the $c y t b$ gene is needed to identify the mechanism conferring resistance; however, other studies have suggested that different mechanisms might be involved in the resistance phenotype. Previous reports have described an alternative respiration pathway sustained by an alternative oxidase (Bohr and Anson 1999; Miguez et al. 2004; Wood and Hollomon 2003) and the expression of a gene coding an efflux transporter that is involved in preventing the accumulation of toxic concentrations of fungicides inside the cells (Andrade et al. 2000; De Waard et al. 2006; Roohparvar et al. 2007). Therefore, we hypothesize that a combination of these mechanisms could be involved in maintaining the resistance of the isolates in this study.

The phenotypic response of benzimidazole resistance in $C$. truncatum isolates was supported by the results of the molecular analysis of the $T U B-2$ gene. Site-specific mutations in this gene have been identified for resistance in several fungal species (Downing 2000), and previous reports determined that mutations leading to the amino acid substitutions of E198A, E198K, and F200Y are involved in conferring resistance to benzimidazole-based fungicides (Jung and Oakley 1990; Peres et al. 2004; Yarden and Katan 1993). In this study, the E198A amino acid substitution was observed in the protein sequence of $C$. truncatum isolates and, to the best of our knowledge, this is the first report of the mutation in this species. We found that $82 \%$ of the fungal isolates with the amino acid substitution at position 198 were considered highly resistant, with $\mathrm{ED}_{50}$ values higher than $300 \mu \mathrm{g} / \mathrm{ml}$. The E198K and F200Y amino acid changes were not observed among the isolates in this study. However, some amino acid substitutions have been noted at other positions that are different from those that are usually reported with benzimidazole resistance, although more work is needed to determine whether these changes are involved in the resistant phenotype or just represent normal allelic variation.

Monitoring fungicide sensitivity is an essential activity for the development of effective control schemes. The results described herein demonstrate the emergence of benzimidazole-based and QoI fungicide-resistant mutants in the $C$. truncatum populations in

Table 6. Mutation and deduced amino acid substitutions in the partial sequence of the TUB-2 gene in Colletotrichum truncatum isolates with different in vitro responses to benzimidazole

\begin{tabular}{lcccc}
\hline & & & \multicolumn{2}{c}{$\begin{array}{c}\text { Sequence in } \\
\text { codon }\end{array}$} \\
\cline { 4 - 5 } Isolate & Response $^{\mathbf{y}}$ & Relative growth $(\boldsymbol{\%})^{\mathbf{z}}$ & $\mathbf{1 9 8}$ & $\mathbf{2 0 0}$ \\
\hline CCP4 & IR & 41.11 & GCG & TTC \\
CCP6 & HR & 71.46 & GCG & TTC \\
CCP27 & HR & 57.91 & GCG & TTC \\
CCP31 & HR & 56.37 & GCG & TTC \\
CCP43 & HR & 52.57 & GCG & TTC \\
CCG9 & HR & 76.22 & GCG & TTC \\
CCG12 & HR & 63.25 & GCG & TTC \\
CCC3 & HR & 61.81 & GCG & TTC \\
CCC18 & HR & 88.93 & GCG & TTC \\
CCC30 & HR & 55.04 & GCG & TTC \\
CCC33 & HR & 63.27 & GAG & TTC \\
CCC38 & IR & 40.51 & GAG & TTC \\
CCC43 & S & 17.92 & GAG & TTC \\
CCC60 & S & 24.96 & GAG & TTC \\
CCG14 & S & 26.59 & GAG & TTC \\
CCJ2 & HR & 67.42 & GAG & TTC \\
CCJ11 & S & 30.63 & GAG & TTC \\
CCJ13 & S & 23.11 & GAG & TTC \\
CCJ19 & S & 32.97 & GAG & TTC \\
CCJ20 & S & 32.18 & GAG & TTC \\
\hline
\end{tabular}

${ }^{\mathrm{y}} \mathrm{HR}=$ high resistance, $\mathrm{IR}=$ intermediate resistance, and $\mathrm{S}=$ susceptible.

${ }^{\mathrm{z}}$ Percent relative growth calculated for the $10,000 \mu \mathrm{g} \mathrm{ml}^{-1}$ concentration.
Mexico. Continuous monitoring programs, either with bioassays or PCR methods detecting mutations in the target genes, are essential to evaluating changes in the effective dose values that lead to the emergence of resistant phenotypes. Monitoring programs would also allow us to understand the population dynamics of the pathogen, according to different chemical control programs, which will aid in the design of adequate and effective management strategies for anthracnose suppression.

\section{Acknowledgments}

This research was funded by the Fundación Produce Quintana Roo through grant 23-2009-1712. We thank J. F. Aguilar for his valuable help with the artwork.

\section{Literature Cited}

Altschul, S. F., Gish, W., Miller, W., Myers, E. W., and Lipman, D. J. 1990. Basic local alignment search tool. J. Mol. Biol. 215:403-410.

Andrade, A. C., del Sorbo, G., Van Nistelrooy, J. G., and de Waard, M. A. 2000 The ABC transporter AtrB from Aspergillus nidulans mediates resistance to all major classes of fungicides and some natural toxic compounds. Microbiology 146:1987-1997.

Astúa, G., Arauz, L. F., and Umaña, G. 1994. Sensibilidad reducida al tiabendazole en Colletotrichum gloeosporioides aislado de papaya. Agron. Costarricense 18: 35-39.

Avila-Adame, C., Olaya, G., and Köller, W. 2003. Characterization of Colletotrichum graminicola isolates resistant to strobilurin-related QoI fungicides. Plant Dis. 87:1426-1432.

Bailey, J. A., and Jeger, M. J., eds. 1992. Colletotrichum: Biology, Pathology and Control. Commonwealth Mycological Institute, Wallingford, UK.

Banno, S., Yamashita, K., Fukumori, F., Okada, K., Uekusa, H., Takagaki, M., Kimura, M., and Fujimura, M. 2009. Characterization of QoI resistance in Botrytis cinerea and identification of two types of mitochondrial cytochrome b gene. Plant Pathol. 58:120-129.

Bartlett, D. W., Clough, J. M., Godwin, J. R., Hall, A. A., Hamer, M., and ParrDobrzanski, B. 2002. The strobilurin fungicides. Pest Manage. Sci. 58:649-662.

Bohr, V. A., and Anson, R. M. 1999. Mitochondrial DNA repair pathways. J. Bioenerg. Biomembr. 31:391-398

Brennan, G. P., Fairweather, I., Trudgett, A., Hoey, E., McCoy, McConville, M., Meaney, M., Robinson, M., McFerran, N., Ryan, L., Lanusse, C., Mottier, L., Alvarez, L., Solana, H., Virkel, G., and Brophy, P. M. 2007. Understanding triclabendazole resistance. Exp. Mol. Pathol. 82:104-109.

Chung, W., Ishii, H., Nishimura, K., Fukaya, M., Yano, K., and Kajitani, Y. 2006. Fungicide sensitivity and phylogenetic relationship of anthracnose fungi isolated from various fruit crops in Japan. Plant Dis. 90:506-512.

Damm, U., Woudenberg, J. H. C., Cannon, P. F., and Crous, P. W. 2009 Colletotrichum species with curved conidia from herbaceous hosts. Fungal Divers. 39:45-87.

De Waard, M. A., Andrade, A. C., Hayashi, K., Schoonbeek, H. J., Stergiopoulos, I., and Zwiers, L. H. 2006. Impact of fungal drug transporters on fungicide sensitivity, multidrug resistance and virulence. Pest Manage. Sci. 62: 195-207.

Downing, K. H. 2000. Structural basis for the action of drugs that affect microtubule dynamics. Emerg. Ther. Targets 4:219-237.

Farman, M. L. 2001. The molecular basis of field resistance to QoI fungicides in Pyricularia grisea. (Abstr.) Phytopathology 91:S110.

Fernández-Ortuño, D., Chen, F., and Schnabel, G. 2012. Resistance to Pyraclostrobin and Boscalid in Botrytis cinerea isolates from strawberry fields in the Carolinas. Plant Dis. 96:1198-1203.

Gisi, U., Sierotzki, H., Cook, A., and McCaffery, A. 2002. Mechanisms influencing the evolution of resistance to Qo inhibitor fungicides. Pest Manage. Sci. 58:859-867.

Grasso, V., Sierotzki, H., Garibaldi, A., and Gisi, U. 2006. Characterization of the cytochrome b gene fragment of Puccinia species responsible for the binding site of QoI fungicides. Pestic. Biochem. Physiol. 84:72-82.

Heaney, S. P., Hall, A. A., Davies, S. A., and Olaya, G. 2000. Resistance to fungicides in the QoI-STAR cross-resistance group: Current perspectives. Pages 755-762 in: Proc. BCPC Conf. Pest Dis. BCPC, Farnham, Surrey, UK.

Jung, M. K., and Oakley, B. R. 1990. Identification of an amino acid substitution in the benA, $\beta$-tubulin gene of Aspergillus nidulans that confers thiabendazole resistance and benomyl supersensitivity. Cell Motil. Cytoskeleton 17:87-94.

Kim, Y.-S., Dixon, E. W., Vincelli, P., and Farman, M. L. 2003. Field resistance to Strobilurin (QoI) fungicides in Pyricularia grisea caused by mutations in the mitochondrial cytochrome b gene. Genet. Res. 93:891-900.

Ma, Z., Felts, D., and Michailides, T. J. 2003. Resistance to azoxystrobin in Alternaria isolates from Pistachio in California. Pestic. Biochem. Physiol. 77:66-74.

Ma, Z., and Michailides, T. J. 2005. Advances in understanding molecular mechanisms of fungicide resistance and molecular detection of resistant genotypes in phytopathogenic fungi. Crop Prot. 24:853-863.

Miguez, M., Reeve, C., Wood, P. M., and Hollomon, D. W. 2004. Alternative oxidase reduces the sensitivity of Mycosphaerella graminicola to QoI fungicides. Pest Manage. Sci. 60:3-7. 
Olaya, G., Cleere, S., Stanger, C., Burbidge, J., Hall, A., and Windass, J. 2003. A novel potential target site to QoI fungicide resistance mechanism in Pythium aphanidermatum. (Abstr.) Phytopathology 93:S67.

Peres, N. A. R., de Souza, N. L., Peever, T. L., and Timmer, L. W. 2004. Benomyl sensitivity of isolates of Colletotrichum acutatum and C. gloeosporioides from Citrus. Plant Dis. 88:125-130.

Roohparvar, R., DeWaard, M., Kema, G. H., and Zwiers, L. H. 2007. MgMfs 1 , a major facilitator superfamily transporter from the fungal wheat pathogen Mycosphaerella graminicola, is a strong protectant against natural toxic compounds and fungicides. Fungal Genet. Biol. 44:378-388.

Sierotzki, H., Frey, R., Wullschleger, J., Palermo, S., Karlin, S., Godwin, J., and Gisi, U. 2007. Cytochrome b gene sequence and structure of Pyrenophora teres and P. tritici-repentis and implications for QoI resistance. Pest Manage. Sci. 63:225-233.

Solano, V., and Arauz, L. F. 1995. Combate de antracnosis en frutos de papaya mediante la aplicación de fungicidas en el campo en la zona atlántica de Costa Rica. Agron. Costarricense 19:25-30.

Stammler, G., Schutte, G. C., Speakman, J., Miessner, S., and Crous, P. W. 2013. Phyllosticta species on citrus: Risk estimation of resistance to QoI fungicides and identification of species with cytochrome $b$ gene sequences. Crop Prot. 48:6-12.

Tapia-Tussell, R., Lappe, P., Ulloa, M., Quijano-Ramayo, A., Cáceres-Farfán, M., Larqué-Saavedra, A., and Perez-Brito, D. 2006. A rapid and simple method for
DNA extraction from yeasts and fungi isolated from Agave fourcroydes. Mol Biotechnol. 33:67-69.

Torres-Calzada, C., Tapia-Tussell, R., Quijano-Ramayo, A., Martin-Mex, R., Rojas-Herrera, R., Higuera-Ciapara, I., and Perez-Brito, D. 2011. A speciesspecific polymerase chain reaction assay for rapid and sensitive detection of Colletotrichum capsici. Mol. Biotechnol. 49:48-55.

Waller, J. M. 1992. Colletotrichum diseases of perennial and other cash crops. Pages 131-142 in: Colletotrichum: Biology, Pathology and Control. J. A Bailey and M. J. Jeger, eds. CABI, Wallingford, UK.

Wong, F. P., de la Cerda, K. A., Hernandez-Martinez, R., and Midland, S. L. 2008. Detection and characterization of benzimidazole resistance in California populations of Colletotrichum cereale. Plant Dis. 92:239-246.

Wood, P. M., and Hollomon, D. W. 2003. A critical evaluation of the role of alternative oxidase in the performance of strobilurin and related fungicides acting at the Qo site of complex III. Pest Manage. Sci. 59:499-511.

Yarden, O., and Katan, T. 1993. Mutations leading to substitutions at amino acids 198 and 200 of beta-tubulin that correlate with benomyl-resistance phenotypes of field strains of Botrytis cinerea. Phytopathology 83:1478-1483.

Yin, Y. N., Kim, Y. K., and Xiao, C. L. 2012. Molecular characterization of pyraclostrobin resistance and structural diversity of the cytochrome $\mathrm{b}$ gene in Botrytis cinerea from apple. Phytopathology 102:315-322. 